Review

\title{
Controlling Cytomegalovirus: Helping the Immune System Take the Lead
}

\section{Patrick J. Hanley * and Catherine M. Bollard}

Program for Cell Enhancement and Technologies for Immunotherapy, Sheikh Zayed Institute for Pediatric Surgical Innovation, and Center for Cancer and Immunology Research, Children's National Health System, Washington, DC 20010, USA; E-Mail: CBollard@childrensnational.org

* Author to whom correspondence should be addressed; E-Mail: PHanley@childrensnational.org; Tel.: +1-202-476-6368; Fax: +1-202-476-5808.

Received: 4 February 2014; in revised form: 9 May 2014 / Accepted: 13 May 2014 /

Published: 27 May 2014

\begin{abstract}
Cytomegalovirus, of the Herpesviridae family, has evolved alongside humans for thousands of years with an intricate balance of latency, immune evasion, and transmission. While upwards of $70 \%$ of humans have evidence of CMV infection, the majority of healthy people show little to no clinical symptoms of primary infection and CMV disease is rarely observed during persistent infection in immunocompetent hosts. Despite the fact that the majority of infected individuals are asymptomatic, immunologically, CMV hijacks the immune system by infecting and remaining latent in antigen-presenting cells that occasionally reactivate subclinically and present antigen to $\mathrm{T}$ cells, eventually causing the inflation of CMV-specific T cells until they can compromise up to $10 \%$ of the entire $\mathrm{T}$ cell repertoire. Because of this impact on the immune system, as well as its importance in fields such as stem cell and organ transplant, the relationship between CMV and the immune response has been studied in depth. Here we provide a review of many of these studies and insights into how CMV-specific T cells are currently being used therapeutically.
\end{abstract}

Keywords: Cytomegalovirus (CMV); Adoptive immunotherapy; T cell; immunotherapy; cellular therapy; transplant 


\section{Biology of Cytomegalovirus}

The virus family Herpesviridae consists of three subfamilies of viruses, alpha, beta, and gamma. Betaherpesviruses contain the four major components of this family: the core, the capsid, the tegument, and the envelope and establish latency in cells of the myeloid lineage and CD34+ cells [1-3]. The tegument contains the majority of virion-associated proteins [4,5]. Tegument proteins have two reported functions, though the proteins that facilitate them are not mutually exclusive [6]. The first function is the disassembly of the virion during entry and assembly of the virion during egress [7]. The second function is inhibiting the host immune response to infection, though as discussed later, they may also promote the response as well [6]. Many of these proteins are associated with immune evasion, and are therefore packaged within the virion and delivered to the host soon after uncoating of the virus. The most abundant tegument protein is the lower matrix phosphoprotein of $65 \mathrm{kDa}(\mathrm{pp} 65)$, or Unique Long (UL)83 [5]. One important function of pp65 is immune evasion. Other tegument proteins devoted to immune evasion include the upper matrix protein pp71, UL36, UL38, and IRS1/TRS1 [8,9].

Immediate early (IE) proteins are translated within $2 \mathrm{~h}$ of infection and do not require the de novo synthesis of viral proteins for their translation [10]. These IE proteins then control subsequently gene expression and virus replication. As such, suppression of IE proteins is thought to contribute to CMV latency whereas the expression of IE genes is associated with reactivation [11]. The laboratories of both Hahn and Fietze have shown that proinflammatory cytokines such as GM-CSF and TNF- $\alpha$ can induce the differentiation of monocytes into macrophages or dendritic cells, which is thought to activate the IE1 promoter and stimulate reactivation [12-14]. However, how cytokines cause HCMV reactivation is still mostly unknown [12,14]. Because IE proteins are expressed first after reactivation, T cells targeting these proteins are of paramount importance, as highlighted in the field of transplantation where $\mathrm{T}$ cells IE proteins are important for protection after solid organ transplant [15].

\section{CMV Infection in the Immune Compromised Host}

CMV has long been one of the most problematic pathogens after stem cell transplantation (SCT) and organ transplant [16-19]. While effective antiviral drugs, viral monitoring, and donor/recipient matching have lowered the likelihood of disease after SCT, the mortality rate in patients who develop CMV-associated pneumonia remains strikingly high (around 80\%-90\%) [17,18]. Additionally, the recipient's CMV-seropositivity remains an independent risk factor for morbidity and mortality after $\mathrm{SCT}$. In the case of SCT, the highest risk of CMV reactivation is when the recipient is seropositive and the stem cell donor is seronegative [20,21]. This is because the recipient has latent (or active) CMV that can no longer be controlled by the recipient's immune system after it is depleted with conditioning regimens and the stem cell donor graft does not contain protective CMV-specific memory $\mathrm{T}$ cells. In contrast, the risk of CMV-related complications, including death, after solid organ transplant (SOT) is greatest when the organ donor is CMV-seropositive and the recipient is CMV-seronegative, though the severity tends to vary based on the organ being transplanted [22-25]. With the advent of CMV prophylaxis, an unexpected complication has emerged with an increased 
incidence of late-onset CMV disease; after day 100, late CMV disease may be as high as $17 \%$ in CMV-seropositive recipients undergoing SCT [26].

\section{Innate Immunity to CMV}

An in-depth review of the immune response to CMV can be found here [9]. Some of the best evidence for the role of the innate immune system in mice is in experiments using beige mice that have known defects in Natural Killer (NK) cell-mediated cytotoxicity and are highly susceptible to murine Cytomegalovirus (MCMV). However, protection against MCMV can be restored by transferring NK cells from normal mice [27]. Despite the elegant studies suggesting the importance of NK cells in controlling MCMV, similar studies in humans are lacking for HCMV [28]. However, Biron et al. have reported in the New England Journal of Medicine NK cell-deficient individuals who are susceptible to herpes virus infections, including HCMV. In vitro experiments using IL-2 activated human NK cells have also demonstrated that NK cells can inhibit CMV replication in CMV-infected fibroblasts by inducing IFN-beta release from infected fibroblasts [29]. Activated NK cells also released IFN-gamma which can impede viral replication [9]. Boehme et al. have shown that HCMV glycoproteins B and H also activate Toll Like Receptor (TLR) 2 on fibroblast, resulting in $\mathrm{NF} \kappa \mathrm{B}$ activation and subsequent inflammatory cytokine secretion, suggesting that NK cells are not the only innate cell responsible for protection from CMV [30]. Indeed, monocytes, macrophages and dendritic cells are cells permissible for viral reactivation and once infected release inflammatory cytokines, in addition to presenting antigen to T cells [31].

\section{Humoral Immunity to CMV}

The importance of an antibody response to CMV is demonstrated in guinea pig models where antibodies protect the animals from reaching a lethal infective dose, but do not prevent infection, suggesting a role for the humoral immune response in limiting the severity of the disease by controlling CMV viral load [32]. After a primary infection in humans, antibodies against a number of proteins from HCMV are detectable in the serum. These antibodies recognize an array of proteins from different parts of the virus, including pp65 and pp150 from the tegument, the glycoproteins $\mathrm{gB}$ and $\mathrm{gH}$ from the envelope, as well as proteins involved in transcription such as IE-1 [33]. Most CMV-seropositive humans have antibodies directed against $\mathrm{gB}$, with over $50 \%$ of all neutralizing antibodies recognizing an epitope of $\mathrm{gB}[33,34]$. The importance of humoral immunity is also demonstrated in congenital CMV infection where pregnant women who develop primary CMV infection carry a $40 \%$ chance of HCMV transmission to the fetus [35,36]. In cases where the mother is able to provide transplacental IgG antibodies, the severity is less [37]. Moreover, identifying a successful vaccine that elicits functional neutralizing antibodies to CMV and can prevent congenital CMV has become a priority [40]. Relevant articles discussing the role of the humoral immune response can be found here [39-41]. 


\section{Cellular Immunity to CMV}

CMV infection commands an overwhelming response from all facets of the immune system. As discussed above, the humoral response and innate response to CMV are indeed significant and contribute to controlling the infection, but the cellular immune response is necessary to control latency and impede viral replication in latently infected individuals (Figure 1) [42]. The most compelling evidence for the immunogenicity of CMV involves the cellular arm of the immune system where up to $10 \%$ of all circulating CD8 $+\mathrm{T}$ cells can be directed towards CMV - a staggering number given the plethora of pathogens we encounter in our lifetime [43]. With the extraordinary percentage of $\mathrm{T}$ cells targeting $\mathrm{CMV}$, it has been postulated that over time, immune surveillance is less effective in $\mathrm{CMV}+$ individuals and, although controversial, CMV-seronegative individuals have been reported to live longer than their CMV-seropositive counterparts [44]. Recent reports on the "aging" of the immune response to CMV have begun to shed light on the mechanism behind this observation $[45,46]$.

Figure 1. Cellular and humoral immunity to Cytomegalovirus.

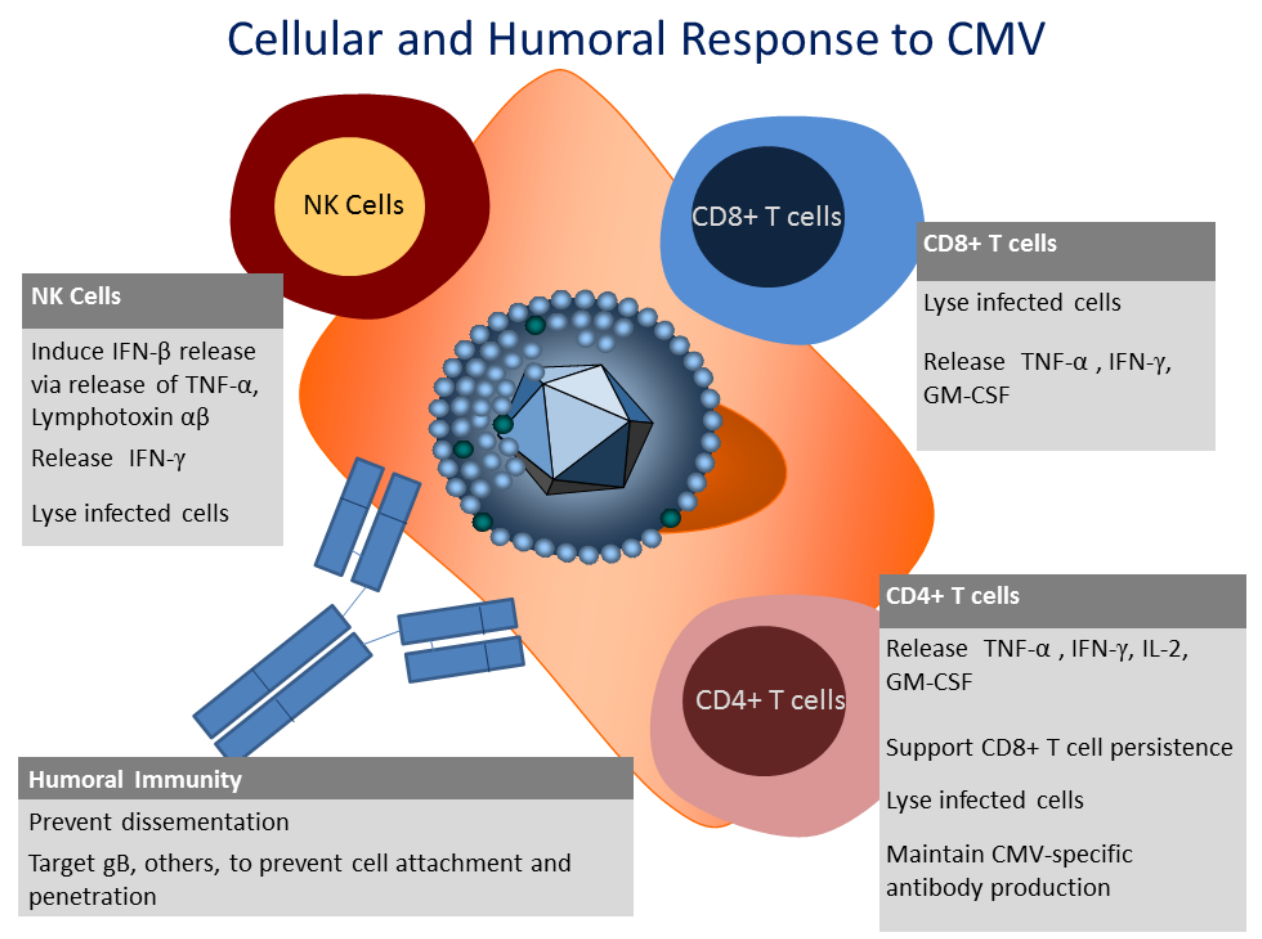

\section{CD8+ T Cell Response to CMV}

The most studied, understood, and manipulated facet of the immune response to CMV is the cellular response, in particular the protective role of CD8+ T cells. The presence of CMV-specific $\mathrm{T}$ cells was first reported in a SCT study noting that the majority of patients without CMV-specific $\mathrm{T}$ cells had overwhelming CMV disease [47]. This led to studies evaluating the ex vivo expansion of CMV specific T cells from CMV-seropositive individuals [48] and the extensive evaluation of the $\mathrm{CMV}$-specific $\mathrm{T}$ cell response in healthy individuals versus immune compromised populations. The importance of CD8 $+\mathrm{T}$ cells has been reported in solid organ transplant as well [49]. In renal transplant recipients, the presence of $\mathrm{CD} 8+\mathrm{T}$ cells coincides with protection from $\mathrm{CMV}$ [50-52] 
and in both heart and lung transplant recipients, the presence of IE-1-specific $\mathrm{T}$ cells correlated with protection from CMV disease [15].

The protectiveness of CD8 $+\mathrm{T}$ cells was first shown in a study by Riddell et al. where $\mathrm{T}$ cells were expanded ex vivo using CMV-infected fibroblasts [48]. Expanded $\mathrm{T}$ cells were then infused into patients after SCT. Riddell et al. reported that prior to the infusion of the T cells, the CMV-specific immunity was undetectable in these patients. However, as early as $48 \mathrm{~h}$ after infusion there was a detectable CMV-specific response and after three weeks the CMV-specific $\mathrm{T}$ cells response was as great or greater than CMV-specific immune responses detected in immunocompetent donors $[48,53]$.

The cell mediated immune response targets proteins in all three of these stages of the viral replication cycle: immediate early, early, and late. By targeting immediate-early and early genes, $\mathrm{T}$ cells can protect against reactivation from latent viruses [54]. Although targeting late proteins would typically delay the cellular response to CMV since these proteins are not expressed until 24-h after infection, many of the late proteins are structural proteins such as the tegument protein pp65 which is already present within the virion and can be immediately presented to $\mathrm{T}$ cells by infected APCs.

In spite of the plethora of CMV antigens targeted by the CD8 $+\mathrm{T}$ cell response, a hierarchy of antigenic frequency exists, though it varies on the method of detection. Collectively, pp65 and the immediate-early 1 (IE-1) are two of the most targeted antigens of CMV by CD8+ T cells $[55,56]$.

\section{CD4+ T Cell Response to CMV}

As is the case with CD8 $+\mathrm{T}$ cells, approximately $9 \%$ of all circulating CD4 $+\mathrm{T}$ cells recognize $\mathrm{CMV}$, an astounding number given the immune repertoire devoted to protection from one pathogen [56]. These $\mathrm{T}$ cells recognize at least 125 open reading frames of CMV or $59 \%$ of all open reading frames. Antigen recognition by $\mathrm{CD} 4+\mathrm{T}$ cells is similar to $\mathrm{CD} 8+\mathrm{T}$ cells in that $\mathrm{T}$ cells recognizing pp65 are some of the most abundant but $\mathrm{T}$ cells recognizing other antigens such as $\mathrm{gB}$, UL86, pp28, IE-2, UL36, UL48, pp10, UL113, and IRS-1 are also highly abundant [56].

The importance of CD4+ $\mathrm{T}$ cells is apparent in a model of CD4-T cell-depleted mice where mice infected with MCMV had an increased incidence of MCMV reactivation [57]. It has also been reported that CD4+ $\mathrm{T}$ cells contribute to controlling MCMV in mice depleted of CD8 $+\mathrm{T}$ cells, but viral clearance is significantly delayed in most tissues and is never cleared from the salivary glands where a persistent infection develops [58].

The significance of CD4+ T cells is better understood and supported in HCMV. Lung transplant recipients with low frequencies of CMV-specific CD4+ T cells have difficulty clearing CMV [49]. In a parallel to the finding in mice, children with CMV who have few CD4+ $\mathrm{T}$ cells have prolonged shedding of CMV in the salivary glands, and dysfunctional CD4+ $\mathrm{T}$ cells have been reported during primary infection [59,60]. Studies from SCT recipients suggest that CD4+ T cells are linked with protection from disease and are necessary for the recovery of donor-derived CD8+ $\mathrm{T}$ cells [61]. What is perhaps more interesting is that the persistence of adoptively transferred $\mathrm{T}$ cells has been reported to depend on the presence of CD4+ T helper cells [53]. 
In the first study of adoptively transferred CMV-specific T cells (predominantly CD8+), no patients developed CMV viremia but only patients who had detectable CD4+ T cell responses showed persistence of the transferred CD8+ T cells [53]. In other words, the highly successful trials mentioned above that utilized CD8 $+\mathrm{T}$ cells specific for various antigens of CMV required not only the transferred CD8+ T cells, but endogenous CD4+ cells as well.

A compelling argument for the role of CD4+ $\mathrm{T}$ cells in immunity to HCMV derives from a study conducted by Einsele et al. in which CD4+ T cells (without CD8+ cells) were transferred to antiviral-resistant SCT recipients with CD4+ T cell deficiencies. Remarkably, all patients exhibited rapid antiviral activity and the cells then persisted at levels similar to immunocompetent healthy donors. Einsele et al. observed that the presence of CD4+ $\mathrm{T}$ cells allowed endogenous CD8+ CMV-specific $\mathrm{T}$ cells to expand, in contrast to transferring CD8+ $\mathrm{T}$ cells that eventually decline without CD4+ T cell help [61].

\section{CMV Evasion from the Immune System}

Through thousands of years of evolution, CMV and humans have reached a balance whereby CMV is able to transmit virus from host-to-host yet not cause significant pathology to immunocompetent individuals. One way CMV is able to persist is by employing numerous immune evasion genes that are expressed in both the unique short (US) and unique long (UL) region of the genome (Table 1) [62]. As with all herpes viruses, CMV interferes with MHC class I presentation to CD8+ T cells in a number of ways. Interestingly, CMV also appears to stealthily modulate the immune response to itself by using decoys and choosing which epitopes and antigens it allows the immune system to target. More specifically, phosphorylation of IE-1 by pp65 blocks the processing of IE-1 in the proteosome [63]. This evasiveness is likely a reason why IE-1 was not identified earlier as an important immunogen of CMV.

Table 1. CMV genes involved in immune evasion.

\begin{tabular}{|c|c|c|}
\hline Mechanism of evasion & CMV Gene product & Effect on immune system \\
\hline MHC Class I down-regulation [64] & US2, US3, US6, US11 & $\begin{array}{l}\text { Decreased presentation of CMV } \\
\text { antigens to CD8+ T cells }\end{array}$ \\
\hline CMV-IE-1 sequestration [63] & UL83 (pp65) & $\begin{array}{l}\text { T cells cannot target first genes } \\
\text { expressed upon reactivation }\end{array}$ \\
\hline MHC Class II down-regulation [65-67] & IE/E product & $\begin{array}{l}\text { Decreased presentation of } \mathrm{CMV} \\
\text { antigens to CD4+ T cells }\end{array}$ \\
\hline MHC Class I homolog [68] & UL18 & Inhibition of NK cell lysis \\
\hline $\begin{array}{c}\text { Inhibitory receptors, downregulation of } \\
\text { ligands }[69,70]\end{array}$ & UL40, UL16, UL142 & Evasion of NK cells \\
\hline Chemokine receptor [71] & US 28 & Immune homing interference \\
\hline IL-10 homolog [1] & UL111a & Immune suppression \\
\hline Inhibitors of apoptosis $[72,73]$ & UL36, UL37 & $\begin{array}{c}\text { Decrease in phagocytosis of infected } \\
\text { cells by APCs }\end{array}$ \\
\hline Downregulation of MICB expression $[74,75]$ & $\begin{array}{l}\text { MicroRNAs } \\
\text { (miR-UL112) }\end{array}$ & $\begin{array}{c}\text { Decreased recognition by NK cells and } \\
\text { T cells via NKG2D }\end{array}$ \\
\hline
\end{tabular}


Another way CMV disrupts antigen presentation is by disrupting the transporter associated with antigen processing (TAP). US6 binds with high affinity to the ER-lumenal side of the transporter, effectively altering the affinity of TAP for ATP. Overall, at least four US genes are involved in down regulation expression of MHC Class I: US2, US3, US6, and US11 [64,76].

Dendritic cells play an important role in the primary immune response to CMV as they orchestrate the priming of naïve $\mathrm{T}$ cells in the lymph nodes. Not surprisingly, CMV targets dendritic cells and halts their maturation, forcing them into a state of functional paralysis and preventing them from presenting CMV antigens to $\mathrm{T}$ cells [62,77]. What's more unexpected is that DCs infected with MCMV are not just unresponsive to MCMV, but MCMV-infected DCs do not secrete IL-12 or IL-2 even after treatment with the potent stimulus lipopolysaccharide (LPS) [77]. It has been suggested that CMV not only evades the immune system, but it also suppresses it. Secondary CMV-associated diseases exist and are a result of CMV modulation of the immune response in ways mentioned above. Additional immunomodulatory genes expressed by CMV and their function are listed in Table 1, but for a more comprehensive review of immune evasion by CMV see the reviews cited here [78-80].

\section{Immunotherapy: Adoptive Transfer of CMV-Specific T Cells after Transplant}

As discussed above, some of the most insightful data about the role of $\mathrm{T}$ cells in protection from CMV came from adoptively transferring $\mathrm{T}$ cells to patients who received stem cell transplants. Since the first method of generation CMV-specific $\mathrm{T}$ cells that was utilized almost 20 years ago by Riddell et al. using CMV-infected fibroblasts to expand $\mathrm{T}$ cells, numerous other methods have been developed to offer protection after SCT [81]. The most common and perhaps most simple is pulsing antigen presenting cells - typically dendritic cells-with overlapping peptides spanning the entire pp65 antigen [82]. Although efficacious, this technique requires the lengthy and difficult generation of DCs, a non-trivial amount of donor-derived blood, and requires highly trained technicians and expensive equipment and manufacturing facilities.

In 2006, Leen, Bollard, and Rooney et al. generated T cells specific for three viruses (CMV, EBV, and adenovirus) by using a recombinant adenovirus that expressed pp65, hereafter named Ad5f35pp65 [83]. This approach utilized monocytes and EBV transformed LCL transduced with the Ad5f35pp65 vector as APCs, thus obviating the need for high volumes of donor blood and targeted 3 viruses in a single culture. While this strategy was effective in vivo and less labor intensive, the expansion of virus-specific $\mathrm{T}$ cells is still a lengthy process that takes upwards of one month, not including the months it takes to generate EBV-LCL [83].

To circumvent the need for multiple expansions and a lengthy expansion process, Peggs et al. recently described a method where they pulsed leukocytes with overlapping peptides for pp65. Activated $\mathrm{T}$ cells are then selected based upon their secretion of IFN-gamma and then frozen for infusion. Including QA/QC testing, total time to infusion was less than two weeks and the entire selection process took $<24 \mathrm{~h}$. However, the risk of such a rapid manufacturing strategy is GVHD since alloreactive $\mathrm{T}$ cells may be still present in the infused product. Indeed, in the Peggs study, most patients were protected from CMV at a dose of only $1 \times 10^{4} \mathrm{CD} 3+$ cells $/ \mathrm{kg}$ but 8 of 18 patients developed acute GvHD, three of which were grade II or higher. Six patients also experienced chronic GvHD [84]. 
Memory $\mathrm{T}$ cells are critical in non-T cell depleted grafts because the virus-specific memory $\mathrm{T}$ cells present in the grafts confer protection against viral infections and reactivation. For this reason, CMV-reactivation is highest when the transplant recipient is CMV-seropositive and the transplant donor is $\mathrm{CMV}$-seronegative, as is often the case in cord blood transplantation and CMV-seronegative donors [85]. Memory T cells are also a valuable resource when expanding virus-specific T cells ex vivo from seropositive donors as these $\mathrm{T}$ cells can be expanded by simply culturing virus-specific memory $\mathrm{T}$ cells with antigen-presenting cells loaded with the antigen of interest. When transferred to transplant recipients after transplant, these cells have been protective against $\mathrm{CMV}, \mathrm{EBV}$, and adenovirus without severe adverse events (Table 2) [83,86]. The challenge, however, has been the ex vivo generation of antigen-specific $\mathrm{T}$ cells from antigen-inexperienced sources of $\mathrm{T}$ cells such as cord blood. Instead of expanding the pre-existing memory $\mathrm{T}$ cell population, naïve $\mathrm{T}$ cells need to be primed in vitro to respond to the antigen of interest [19].

Table 2. Studies of adoptively transferred CMV-specific T cells.

\begin{tabular}{cc}
\hline Group & Method of Expansion/Selection \\
\hline Riddell, 1992, 1995 [48,53] & Expansion using CMV-infected fibroblasts \\
Einsele, 2002 [61] & Expansion with CMV lysate \\
Cobbold, 2005 [87] & Tetramer Selection using magnetic beads \\
Leen, 2006 [83] & Antigen-presenting cells (Dendritic cells, EBV-LCL) transduced with an \\
& adenoviral vector encoding CMVpp65 \\
Micklethwaite, 2008 [86] & Antigen-presenting cells (Dendritic cells) transduced with an adenoviral \\
veggs, 2011 [84] & vector encoding CMVpp65 \\
Hanley, 2012 [88] & Selection of T cells secreting IFN- $\gamma$ after exposure to CMV antigen \\
& Antigen-presenting cells (Dendritic cells, EBV-LCL) transduced with an \\
Blyth, 2013 [89] & adenoviral vector encoding CMVp65 \\
& Antigen-presenting cells (Dendritic cells) transduced with an adenoviral \\
vector encoding CMVpp65 or Dendritic cells pulsed with \\
HLA-A02-restricted peptide NLVPMVATV
\end{tabular}

Because of these challenges, only a few reports document the generation of single antigen-specific $\mathrm{T}$ cells from naive donors [90-93]. In an attempt to target 3 viruses simultaneously, our group reported the ability to generate CMV, EBV, and adenovirus-specific CTL from the $20 \%$ fraction of a cord blood unit by using dendritic cells transduced with an Ad5/f35-CMV-pp65 vector as well as the cytokines IL-7, IL-12, and IL-15 [94]. Responding T cells were shown to be derived from the naïve $\mathrm{T}$ cell population and responded to typical and atypical, novel CMV-pp65 epitopes. A clinical trial using CB-derived multi-virus specific $\mathrm{T}$ cells for the prevention and treatment of viral infection after CBT is open and has started to accrue patients. (Clinical Trial \#: NCT01017705) [81,88]. Recently, we and other groups have also reported the ability to generate CMV-specific $\mathrm{T}$ cells from CMV-seronegative donors; $[95,96]$ the clinical efficacy of these T cells will be tested in a Phase 1 clinical study (Clinical Trial \#: NCT01945814).

Another option for recipients of $\mathrm{CB}$ and $\mathrm{CMV}$-seronegative donors is the use of third party, CMV-specific $\mathrm{T}$ cells. Thirdy party virus specific $\mathrm{T}$ cells have been evaluated clinically in several trials with promising results [97-101]. Leen et al. recently published a multi-institutional study of 
best-matched, MULTI virus-specific T cells and reported that responses with third party CTL were similar to those from donor-derived CTL in their previous studies $[83,100]$. This study highlights the importance of epitope recognition when selecting the optimal third party $\mathrm{T}$ cell lines.

\section{Summary}

The human body has done an exquisite job over thousands of years to prevent or impede the manifestations of CMV and as a result, the majority of the population can live with CMV without knowing they have it. However, when the balance shifts towards CMV reactivation, usually as a result of treatment modalities or in some cases other infections, options are available to treat CMV infection, and the use of immunotherapy is rapidly becoming one of the favored options. The use of third-party, epitope-targeted CMV-specific $\mathrm{T}$ cells provides a unique platform similar to other pharmacotherapies in that they are rapidly available, are short lived, are effective, and are not associated with significant toxicities. However, for chronically suppressed patients, such as those undergoing SOT, the use of autologous CMV-specific $\mathrm{T}$ cells might be the ideal solution as long-term protection is necessary. Overall, improvements to $\mathrm{T}$ cell manufacturing technologies will provide a new and widely used treatment for CMV infection after transplant.

\section{Acknowledgments}

This work was supported by a post-doctoral fellowship, PF-13-046-01-LIB from the American Cancer Society awarded to PJH, and CPRIT RO1 RP100469 and NCI PO1 CA148600-02 awards to $\mathrm{CMB}$.

\section{Author Contributions}

P.J.H. and C.M.B. both contributed to writing the manuscript.

\section{Conflicts of Interest}

The authors declare no conflict of interest.

\section{References and Notes}

1. Cheung, A.K.; Gottlieb, D.J.; Plachter, B.; Pepperl-Klindworth, S.; Avdic, S.; Cunningham, A.L.; Abendroth, A.; Slobedman, B. The role of the human cytomegalovirus UL111A gene in down-regulating CD4+ T-cell recognition of latently infected cells: Implications for virus elimination during latency. Blood 2009, 114, 4128-4137.

2. Goodrum, F.D.; Jordan, C.T.; High, K.; Shenk, T. Human cytomegalovirus gene expression during infection of primary hematopoietic progenitor cells: A model for latency. Proc. Natl. Acad. Sci. USA 2002, 99, 16255-16260.

3. Reeves, M.B.; Sinclair, J.H. Analysis of latent viral gene expression in natural and experimental latency models of human cytomegalovirus and its correlation with histone modifications at a latent promoter. J. Gen. Virol. 2010, 91, 599-604. 
4. Varnum, S.M.; Streblow, D.N. Monroe, M.E.; Smith, P.; Auberry, K.J.; Pasa-Tolic, L.; Wang, D.; Camp, D.G., Jr.; Rodland, K.; Wiley, S.; et al. Identification of proteins in human cytomegalovirus (HCMV) particles: The HCMV proteome. J. Virol. 2004, 78, 10960-10966.

5. Kalejta, R.F. Tegument proteins of human cytomegalovirus. Microbiol. Mol. Biol. Rev. 2008, 72 , 249-265.

6. Human Herpesviruses: Biology, Therapy, and Immunoprophylaxis; Arvin, A., Campadelli-Fiume, G., Mocarski, E., Moore, P.S., Roizman, B., Whitley, R., Yamanishi, K., Eds.; Cambridge University Press: Cambridge, UK, 2007.

7. Roby, C.; Gibson, W. Characterization of phosphoproteins and protein kinase activity of virions, noninfectious enveloped particles, and dense bodies of human cytomegalovirus. J. Virol. 1986, 59, 714-727.

8. Gandhi, M.K.; Khanna, R. Human cytomegalovirus: Clinical aspects, immune regulation, and emerging treatments. Lancet Infect. Dis. 2004, 4, 725-738.

9. Loewendorf, A.; Benedict, C.A. Modulation of host innate and adaptive immune defenses by cytomegalovirus: Timing is everything. J. Intern. Med. 2010, 267, 483-501.

10. Sissons, J.G.; Bain, M.; Wills, M.R. Latency and reactivation of human cytomegalovirus. J. Infect. 2002, 44, 73-77.

11. Paulus, C.; Nevels, M. The human cytomegalovirus major immediate-early proteins as antagonists of intrinsic and innate antiviral host responses. Viruses 2009, 1, 760-779.

12. Hahn, G.; Jores, R.; Mocarski, E.S. Cytomegalovirus remains latent in a common precursor of dendritic and myeloid cells. Proc. Natl. Acad. Sci. USA 1998, 95, 3937-3942.

13. Gerna, G.; Percivalle, E.; Lilleri, D.; Lozza, L.; Fornara, C.; Hahn, G.; Baldanti, F.; Revello, M.G. Dendritic-cell infection by human cytomegalovirus is restricted to strains carrying functional UL131-128 genes and mediates efficient viral antigen presentation to CD8+ $\mathrm{T}$ cells. J. Gen. Virol. 2005, 86, 275-284.

14. Fietze, E.; Prosch, S.; Reinke, P.; Stein, J.; Docke, W.D.; Staffa, G.; Löning, S.; Devaux, S.; Emmrich, F.; von Baehr, R. Cytomegalovirus infection in transplant recipients. The role of tumor necrosis factor. Transplantation 1994, 58, 675-680.

15. Bunde, T.; Kirchner, A.; Hoffmeister, B.; Habedank, D.; Hetzer, R.; Cherepnev, G.; Proesch, S.; Reinke, P.; Volk, H.D.; Lehmkuhl, H.; et al. Protection from cytomegalovirus after transplantation is correlated with immediate early 1-specific CD8 T cells. J. Exp. Med. 2005, 201, 1031-1036.

16. Kennedy-Nasser, A.A.; Bollard, C.M.; Myers, G.D.; Leung, K.S.; Gottschalk, S.; Zhang, Y.; Liu, H.; Heslop, H.E.; Brenner, M.K.; Krance, R.A. Comparable outcome of alternative donor and matched sibling donor hematopoietic stem cell transplant for children with acute lymphoblastic leukemia in first or second remission using alemtuzumab in a myeloablative conditioning regimen. Biol. Blood Marrow Transplant. 2008, 14, 1245-1252.

17. Mori, T.; Kato, J. Cytomegalovirus infection/disease after hematopoietic stem cell transplantation. Int. J. Hematol. 2010, 91, 588-595.

18. Boeckh, M.; Nichols, W.G. The impact of cytomegalovirus serostatus of donor and recipient before hematopoietic stem cell transplantation in the era of antiviral prophylaxis and preemptive therapy. Blood 2004, 103, 2003-2008. 
19. Hanley, P.J.; Cruz, C.R.; Shpall, E.J.; Bollard, C.M. Improving clinical outcomes using adoptively transferred immune cells from umbilical cord blood. Cytotherapy 2010, 12, 713-720.

20. Ugarte-Torres, A.; Hoegh-Petersen, M.; Liu, Y.; Zhou, F.; Williamson, T.S.; Quinlan, D.; Sy, S.; Roa, L.; Khan, F.; Fonseca, K.; et al. Donor serostatus has an impact on cytomegalovirus-specific immunity, cytomegaloviral disease incidence, and survival in seropositive hematopoietic cell transplant recipients. Biol. Blood Marrow Transplant. 2011, 17, 574-585.

21. Jaskula, E.; Bochenska, J.; Kocwin, E.; Tarnowska, A.; Lange, A. CMV Serostatus of Donor-Recipient Pairs Influences the Risk of CMV Infection/Reactivation in HSCT Patients. Bone Marrow Res. 2012, 2012, 375075.

22. Falagas, M.E.; Paya, C.; Ruthazer, R.; Badley, A.; Patel, R.; Wiesner, R.; Griffith, J.; Freeman, R.; Rohrer, R.; Werner, B.G.; et al. Significance of cytomegalovirus for long-term survival after orthotopic liver transplantation: A prospective derivation and validation cohort analysis. Transplantation 1998, 66, 1020-1028.

23. Paya, C.V. Prevention of cytomegalovirus disease in recipients of solid-organ transplants. Clin. Infect. Dis. 2001, 32, 596-603.

24. Cope, A.V.; Sabin, C.; Burroughs, A.; Rolles, K.; Griffiths, P.D.; Emery, V.C. Interrelationships among quantity of human cytomegalovirus (HCMV) DNA in blood, donor-recipient serostatus, and administration of methylprednisolone as risk factors for HCMV disease following liver transplantation. J. Infect. Dis. 1997, 176, 1484-1490.

25. Sia, I.G.; Wilson, J.A.; Groettum, C.M.; Espy, M.J.; Smith, T.F.; Paya, C.V. Cytomegalovirus (CMV) DNA load predicts relapsing CMV infection after solid organ transplantation. J. Infect. Dis. 2000, 181, 717-720.

26. Boeckh, M. Current antiviral strategies for controlling cytomegalovirus in hematopoietic stem cell transplant recipients: Prevention and therapy. Transpl. Infect. Dis. 1999, 1, 165-178.

27. Shellam, G.R.; Allan, J.E.; Papadimitriou, J.M.; Bancroft, G.J. Increased susceptibility to cytomegalovirus infection in beige mutant mice. Proc. Natl. Acad. Sci. USA 1981, 78, 5104-5108.

28. Biron, C.A.; Byron, K.S.; Sullivan, J.L. Severe herpesvirus infections in an adolescent without natural killer cells. N. Engl. J. Med. 1989, 320, 1731-1735.

29. Iversen, A.C.; Norris, P.S.; Ware, C.F.; Benedict, C.A.; Human, N.K. Cells inhibit cytomegalovirus replication through a noncytolytic mechanism involving lymphotoxin-dependent induction of IFN-beta. J. Immunol. 2005, 175, 7568-7574.

30. Boehme, K.W.; Guerrero, M.; Compton, T. Human cytomegalovirus envelope glycoproteins B and $\mathrm{H}$ are necessary for TLR2 activation in permissive cells. J. Immunol. 2006, 177, 7094-7102.

31. Rossini, G.; Cerboni, C.; Santoni, A.; Landini, M.P.; Landolfo, S.; Gatti, D.; Gribaudo, G.; Varani, S. Interplay between human cytomegalovirus and intrinsic/innate host responses: A complex bidirectional relationship. Mediat. Inflamm. 2012, 2012, 607276.

32. Bratcher, D.F.; Bourne, N.; Bravo, F.J.; Schleiss, M.R.; Slaoui, M.; Myers, M.G.; Bernstein, D.I. Effect of passive antibody on congenital cytomegalovirus infection in guinea pigs. J. Infect. Dis. 1995, 172, 944-950. 
33. Britt, W.J.; Vugler, L.; Butfiloski, E.J.; Stephens, E.B. Cell surface expression of human cytomegalovirus (HCMV) gp55-116 (gB): Use of HCMV-recombinant vaccinia virus-infected cells in analysis of the human neutralizing antibody response. J. Virol. 1990, 64, 1079-1085.

34. Gonczol, E.; deTaisne, C.; Hirka, G.; Berencsi, K.; Lin, W.C.; Paoletti, E.; Plotkin, S. High expression of human cytomegalovirus (HCMV)-gB protein in cells infected with a vaccinia-gB recombinant: The importance of the gB protein in HCMV immunity. Vaccine 1991, 9, 631-637.

35. Stagno, S.; Pass, R.F.; Cloud, G.; Britt, W.J.; Henderson, R.E.; Walton, P.D.; Veren, D.A.; Page, F.; Alford, C.A. Primary cytomegalovirus infection in pregnancy. Incidence, transmission to fetus, and clinical outcome. J. Am. Med. Assoc. (JAMA) 1986, 256, 1904-1908.

36. Revello, M.G.; Gerna, G. Diagnosis and management of human cytomegalovirus infection in the mother, fetus, and newborn infant. Clin. Microbiol. Rev. 2002, 15, 680-715.

37. Schleiss, M.R. Cytomegalovirus in the neonate: Immune correlates of infection and protection. Clin. Dev. Immunol. 2013, 2013, 501801.

38. Krause, P.R.; Bialek, S.R.; Boppana, S.B.; Griffiths, P.D.; Laughlin, C.A.; Ljungman, P.; Ljungman, P.; Mocarski, E.S.; Pass, R.F.; Read, J.S.; et al. Priorities for CMV vaccine development. Vaccine 2013, 32, 4-10.

39. Alonso Arias, R.; Moro-Garcia, M.A.; Echeverria, A.; Solano-Jaurrieta, J.J.; Suarez-Garcia, F.M.; Lopez-Larrea, C. Intensity of the humoral response to cytomegalovirus is associated with the phenotypic and functional status of the immune system. J. Virol. 2013, 87, 4486-4495.

40. Zhu, J.; Shearer, G.M.; Marincola, F.M.; Norman, J.E.; Rott, D.; Zou, J.P.; Epstein, S.E. Discordant cellular and humoral immune responses to cytomegalovirus infection in healthy blood donors: Existence of a Th1-type dominant response. Int. Immunol. 2001, 13, 785-790.

41. Landini, M.P.; Lazzarotto, T.; Xu, J.; Geballe, A.P.; Mocarski, E.S. Humoral immune response to proteins of human cytomegalovirus latency-associated transcripts. Biol. Blood Marrow Transplant. 2000, 6, 100-108.

42. Moss, P.; Rickinson, A. Cellular immunotherapy for viral infection after HSC transplantation. Nat. Rev. Immunol. 2005, 5, 9-20.

43. Crough, T.; Khanna, R. Immunobiology of human cytomegalovirus: From bench to bedside. Clin. Microbiol. Rev. 2009, 22, 76-98.

44. Olsson, J.; Wikby, A.; Johansson, B.; Lofgren, S.; Nilsson, B.O.; Ferguson, F.G. Age-related change in peripheral blood T-lymphocyte subpopulations and cytomegalovirus infection in the very old: The Swedish longitudinal OCTO immune study. Mech. Ageing Dev. 2000, 121, 187-201.

45. Spielmann, G.; Bollard, C.M.; Bigley, A.B.; Hanley, P.J.; Blaney, J.W.; Lavoy, E.C.; Pircher, H.; Simpson, R.J. The effects of age and latent cytomegalovirus infection on the redeployment of CD8+ T cell subsets in response to acute exercise in humans. Brain, Behav, Immunity 2013, doi:10.1016/j.bbi.2013.05.003.

46. Simpson, R.J.; Lowder, T.W.; Spielmann, G.; Bigley, A.B.; LaVoy, E.C.; Kunz, H. Exercise and the aging immune system. Ageing Res. Rev. 2012, 11, 404-420.

47. Reusser, P.; Riddell, S.R.; Meyers, J.D.; Greenberg, P.D. Cytotoxic T-lymphocyte response to cytomegalovirus after human allogeneic bone marrow transplantation: Pattern of recovery and correlation with cytomegalovirus infection and disease. Blood 1991, 78, 1373-1380. 
48. Riddell, S.R.; Watanabe, K.S.; Goodrich, J.M.; Li, C.R.; Agha, M.E.; Greenberg, P.D. Restoration of viral immunity in immunodeficient humans by the adoptive transfer of $\mathrm{T}$ cell clones. Science 1992, 257, 238-241.

49. Sester, U.; Gartner, B.C.; Wilkens, H.; Schwaab, B.; Wossner, R.; Kindermann, I.; Girndt, M.; Meyerhans, A.; Mueller-Lantzsch, N.; Schäfers, H.J. Differences in CMV-specific T-cell levels and long-term susceptibility to CMV infection after kidney, heart and lung transplantation. Am. J. Transplant. 2005, 5, 1483-1489.

50. Radha, R.; Jordan, S.; Puliyanda, D.; Bunnapradist, S.; Petrosyan, A.; Amet, N.; Toyoda, M. Cellular immune responses to cytomegalovirus in renal transplant recipients. Am. J. Transplant. 2005, 5, 110-117.

51. Reusser, P.; Cathomas, G.; Attenhofer, R.; Tamm, M.; Thiel, G. Cytomegalovirus (CMV)-specific $\mathrm{T}$ cell immunity after renal transplantation mediates protection from CMV disease by limiting the systemic virus load. J. Infect. Dis. 1999, 180, 247-253.

52. Sester, M.; Sester, U.; Gartner, B.C.; Girndt, M.; Meyerhans, A.; Kohler, H. Dominance of virus-specific CD8 T cells in human primary cytomegalovirus infection. J. Am. Soc. Nephrol. (JASN) 2002, 13, 2577-2584.

53. Walter, E.A.; Greenberg, P.D.; Gilbert, M.J.; Finch, R.J.; Watanabe, K.S.; Thomas, E.D.; Riddell, S.R. Reconstitution of cellular immunity against cytomegalovirus in recipients of allogeneic bone marrow by transfer of T-cell clones from the donor. N. Engl. J. Med. 1995, 333, 1038-1044.

54. Hanley, P.J.; Shaffer, D.R.; Cruz, C.R.; Ku, S.; Tzou, B.; Liu, H.; Demmler-Harrison, G.; Heslop, H.E.; Rooney, C.M.; Gottschalk, S.; et al. Expansion of T cells targeting multiple antigens of cytomegalovirus, Epstein-Barr virus and adenovirus to provide broad antiviral specificity after stem cell transplantation. Cytotherapy 2011, 13, 976-986.

55. Wills, M.R.; Carmichael, A.J.; Mynard, K.; Jin, X.; Weekes, M.P.; Plachter, B.; Sissons, J.G. The human cytotoxic T-lymphocyte (CTL) response to cytomegalovirus is dominated by structural protein pp65: Frequency, specificity, and T-cell receptor usage of pp65-specific CTL. J. Virol. 1996, 70, 7569-7579.

56. Sylwester, A.W.; Mitchell, B.L.; Edgar, J.B.; Taormina, C.; Pelte, C.; Ruchti, F.; Sleath, P.R.; Grabstein, K.H.; Hosken, N.A.; Kern, F.; et al. Broadly targeted human cytomegalovirus-specific CD4+ and CD8+ T cells dominate the memory compartments of exposed subjects. J. Exp. Med. 2005, 202, 673-685.

57. Polic, B.; Hengel, H.; Krmpotic, A.; Trgovcich, J.; Pavic, I.; Luccaronin, P.; Jonjić, S.; Koszinowski, U.H. Hierarchical and redundant lymphocyte subset control precludes cytomegalovirus replication during latent infection. J. Exp. Med. 1998, 188, 1047-1054.

58. Jonjic, S.; Pavic, I.; Lucin, P.; Rukavina, D.; Koszinowski, U.H. Efficacious control of cytomegalovirus infection after long-term depletion of CD8+ T lymphocytes. J. Virol. 1990, 64, 5457-5464.

59. Tu, W.; Chen, S.; Sharp, M.; Dekker, C.; Manganello, A.M.; Tongson, E.C.; Maecker, H.T.; Holmes, T.H.; Wang, Z.; Kemble, G.; et al. Persistent and selective deficiency of CD4+ T cell immunity to cytomegalovirus in immunocompetent young children. J. Immunol. 2004, 172, 3260-3267. 
60. Antoine, P.; Olislagers, V.; Huygens, A.; Lecomte, S.; Liesnard, C.; Donner, C.; Marchant, A. Functional exhaustion of CD4+ T lymphocytes during primary cytomegalovirus infection. J. Immunol. 2012, 189, 2665-2672.

61. Einsele, H.; Roosnek, E.; Rufer, N.; Sinzger, C.; Riegler, S.; Loffler, J.; Grigoleit, U.; Moris, A.; Rammensee, H.G.; Kanzm L.; et al. Infusion of cytomegalovirus (CMV)-specific T cells for the treatment of CMV infection not responding to antiviral chemotherapy. Blood 2002, 99, 3916-3922.

62. Lehner, P.J.; Wilkinson, G.W. Cytomegalovirus: From evasion to suppression? Nat. Immunol. 2001, 2, 993-994.

63. Gilbert, M.J.; Riddell, S.R.; Plachter, B.; Greenberg, P.D. Cytomegalovirus selectively blocks antigen processing and presentation of its immediate-early gene product. Nature 1996, 383, 720-722.

64. Park, B.; Oh, H.; Lee, S.; Song, Y.; Shin, J.; Sung, Y.C.; Hwang, S.Y.; Ahn, K. The MHC class I homolog of human cytomegalovirus is resistant to down-regulation mediated by the unique short region protein (US)2, US3, US6, and US11 gene products. J. Immunol. 2002, 168, 3464-3469.

65. Miller, D.M.; Rahill, B.M.; Boss, J.M.; Lairmore, M.D.; Durbin, J.E.; Waldman, J.W.; Sedmak, D.D. Human cytomegalovirus inhibits major histocompatibility complex class II expression by disruption of the Jak/Stat pathway. J. Exp. Med. 1998, 187, 675-683.

66. Le Roy, E.; Muhlethaler-Mottet, A.; Davrinche, C.; Mach, B.; Davignon, J.L. Escape of human cytomegalovirus from HLA-DR-restricted CD4(+) T-cell response is mediated by repression of gamma interferon-induced class II transactivator expression. J. Virol. 1999, 73, 6582-6589.

67. Tomazin, R.; Boname, J.; Hegde, N.R.; Lewinsohn, D.M.; Altschuler, Y.; Jones, T.R.; Cresswell, P.; Nelson, J.A.; Riddell, S.R.; Johnson, D.C. Cytomegalovirus US2 destroys two components of the MHC class II pathway, preventing recognition by CD4+ T cells. Nat. Med. 1999, 5, 1039-1043.

68. Reyburn, H.T.; Mandelboim, O.; Vales-Gomez, M.; Davis, D.M.; Pazmany, L.; Strominger, J.L. The class I MHC homologue of human cytomegalovirus inhibits attack by natural killer cells. Nature 1997, 386, 514-517.

69. Wang, E.C.; McSharry, B.; Retiere, C.; Tomasec, P.; Williams, S.; Borysiewicz, L.K.; Braud, V.M.; Wilkinson, G.W. UL40-mediated NK evasion during productive infection with human cytomegalovirus. Proc. Natl. Acad. Sci. USA 2002, 99, 7570-7575.

70. Dunn, C.; Chalupny, N.J.; Sutherland, C.L.; Dosch, S.; Sivakumar, P.V.; Johnson, D.C.; Cosman, D. Human cytomegalovirus glycoprotein UL16 causes intracellular sequestration of NKG2D ligands, protecting against natural killer cell cytotoxicity. J. Exp. Med. 2003, 197, 1427-1439.

71. Casarosa, P.; Bakker, R.A.; Verzij1, D.; Navis, M.; Timmerman, H.; Leurs, R.; Martine, J.S. Constitutive signaling of the human cytomegalovirus-encoded chemokine receptor US28. J. Biol. Chem. 2001, 276, 1133-1137.

72. Skaletskaya, A.; Bartle, L.M.; Chittenden, T.; McCormick, A.L.; Mocarski, E.S.; Goldmacher, V.S. A cytomegalovirus-encoded inhibitor of apoptosis that suppresses caspase-8 activation. Proc. Natl. Acad. Sci. USA 2001, 98, 7829-7834. 
73. Zhang, A.; Hildreth, R.L.; Colberg-Poley, A.M. Human cytomegalovirus inhibits apoptosis by proteasome-mediated degradation of Bax at endoplasmic reticulum-mitochondrion contacts. J. Virol. 2013, 87, 5657-5668.

74. Stern-Ginossar, N.; Elefant, N.; Zimmermann, A.; Wolf, D.G.; Saleh, N.; Biton, M.; Horwitz, E.; Prokocimer, Z.; Prichard, M.; Hahn, G.; et al. Host immune system gene targeting by a viral miRNA. Science 2007, 317, 376-381.

75. Stern-Ginossar, N.; Gur, C.; Biton, M.; Horwitz, E.; Elboim, M.; Stanietsky, N.; Mandelboim, M.; Mandelboim, O. Human microRNAs regulate stress-induced immune responses mediated by the receptor NKG2D. Nat. Immunol. 2008, 9, 1065-1073.

76. Mocarski, E.S., Jr. Immunomodulation by cytomegaloviruses: Manipulative strategies beyond evasion. Trends Microbiol. 2002, 10, 332-339.

77. Andrews, D.M.; Andoniou, C.E.; Granucci, F.; Ricciardi-Castagnoli, P.; Degli-Esposti, M.A. Infection of dendritic cells by murine cytomegalovirus induces functional paralysis. Nat. Immunol. 2001, 2, 1077-1084.

78. Noriega, V.; Redmann, V.; Gardner, T.; Tortorella, D. Diverse immune evasion strategies by human cytomegalovirus. Immunol. Res. 2012, 54, 140-151.

79. Miller-Kittrell, M.; Sparer, T.E. Feeling manipulated: Cytomegalovirus immune manipulation. Virol. J. 2009, 6, doi:10.1186/1743-422X-6-4.

80. Jackson, S.E.; Mason, G.M.; Wills, M.R. Human cytomegalovirus immunity and immune evasion. Virus Res. 2011, 157, 151-160.

81. Saglio, F.; Hanley, P.J.; Bollard, C.M. The time is now: Moving toward virus-specific T cells after allogeneic hematopoietic stem cell transplantation as the standard of care. Cytotherapy 2014, 16, 149-159.

82. Gerdemann, U.; Katari, U.L.; Papadopoulou, A.; Keirnan, J.M.; Craddock, J.A.; Liu, H.; Martinez, C.A.; Kennedy-Nasser, A.; Leung, K.S.; Gottschalk, S.M.; et al. Safety and clinical efficacy of rapidly-generated trivirus-directed $\mathrm{T}$ cells as treatment for adenovirus, $\mathrm{EBV}$, and CMV infections after allogeneic hematopoietic stem cell transplant. Mol. Ther. 2013, 21, 2113-2121.

83. Leen, A.M.; Myers, G.D.; Sili, U.; Huls, M.H.; Weiss, H.; Leung, K.S.; Carrum, G.; Krance, R.A.; Chang, C.C.; Molldrem, J.J.; et al. Monoculture-derived T lymphocytes specific for multiple viruses expand and produce clinically relevant effects in immunocompromised individuals. Nat. Med. 2006, 12, 1160-1166.

84. Peggs, K.S.; Thomson, K.; Samuel, E.; Dyer, G.; Armoogum, J.; Chakraverty, R.; Pang, K.; Mackinnon, S.; Lowdell, M.W. Directly selected cytomegalovirus-reactive donor $\mathrm{T}$ cells confer rapid and safe systemic reconstitution of virus-specific immunity following stem cell transplantation. Clin. Infect. Dis. 2011, 52, 49-57.

85. Kroger, N.; Zabelina, T.; Kruger, W.; Renges, H.; Stute, N.; Schrum, J.; Kabisch, H.; Schafhausen, P.; Jaburg, N.; Löliger, C.; et al. Patient cytomegalovirus seropositivity with or without reactivation is the most important prognostic factor for survival and treatment-related mortality in stem cell transplantation from unrelated donors using pretransplant in vivo T-cell depletion with anti-thymocyte globulin. Br. J. Haematol. 2001, 113, 1060-1071. 
86. Micklethwaite, K.P.; Clancy, L.; Sandher, U.; Hansen, A.M.; Blyth, E.; Antonenas, V.; Sartor, M.M.; Bradstock, K.F.; Gottlieb, D.J. Prophylactic infusion of cytomegalovirus-specific cytotoxic $\mathrm{T}$ lymphocytes stimulated with Ad5f35pp65 gene-modified dendritic cells after allogeneic hemopoietic stem cell transplantation. Blood 2008, 112, 3974-3981.

87. Cobbold, M.; Khan, N.; Pourgheysari, B.; Tauro, S.; McDonald, D.; Osman, H.; Assenmacher, M.; Billingham, L.; Colin. Adoptive transfer of cytomegalovirus-specific CTL to stem cell transplant patients after selection by HLA-peptide tetramers. J. Exp. Med. 2005, 202, 379-386.

88. Hanley, P.J.; Martinez, C.; Leung, K.; Savoldo, B.; Dotti, G.; Brenner, M.K.; Rooney, C.; Heslop, H.; Krance, R.; Shpall, E.J.; et al. Improving Immune Reconstitution after cord blood transplantation using ex vivo expanded virus-specific $\mathrm{T}$ cells: A phase I clinical study. ASH Annu. Meet. Abstr. 2013, 15, S21.

89. Blyth, E.; Clancy, L.; Simms, R.; Ma, C.K.; Burgess, J.; Deo, S.; Byth, K.; Dubosq, M.C.; Shaw, P.J.; Micklethwaite, K.P.; et al. Donor-derived CMV-specific $\mathrm{T}$ cells reduce the requirement for CMV-directed pharmacotherapy after allogeneic stem cell transplantation. Blood 2013, 121, 3745-3758.

90. Sun, Q.; Burton, R.L.; Pollok, K.E.; Emanuel, D.J.; Lucas, K.G. CD4(+) Epstein-Barr virus-specific cytotoxic T-lymphocytes from human umbilical cord blood. Cell. Immunol. 1999, 195, 81-88.

91. Savoldo, B.; Cubbage, M.L.; Durett, A.G.; Goss, J.; Huls, M.H.; Liu, Z.; Teresita, L.; Gee, A.P.; Ling, P.D.; Brenner, M.K.; et al. Generation of EBV-specific CD4+ cytotoxic T cells from virus naive individuals. J. Immunol. 2002, 168, 909-918.

92. Park, K.D.; Marti, L.; Kurtzberg, J.; Szabolcs, P. In vitro priming and expansion of cytomegalovirus-specific Th1 and Tc1 T cells from naive cord blood lymphocytes. Blood 2006, 108, 1770-1773.

93. Hanley, P.J.; Lam, S.; Shpall, E.J.; Bollard, C.M. Expanding cytotoxic T lymphocytes from umbilical cord blood that target cytomegalovirus, Epstein-Barr virus, and adenovirus. J. Vis. Exp. 2012, e3627, doi:10.3791/3627.

94. Hanley, P.J.; Cruz, C.R.; Savoldo, B.; Leen, A.M.; Stanojevic, M.; Khalil, M.; Decker, W.; Molldrem, J.J.; Liu, H.; Gee, A.P.; et al. Functionally active virus-specific T cells that target $\mathrm{CMV}$, adenovirus, and EBV can be expanded from naive T-cell populations in cord blood and will target a range of viral epitopes. Blood 2009, 114, 1958-1967.

95. Jedema, I.; van de Meent, M.; Pots, J.; Kester, M.G.; van der Beek, M.T.; Falkenburg, J.H. Successful generation of primary virus-specific and anti-tumor T-cell responses from the naive donor T-cell repertoire is determined by the balance between antigen-specific precursor $\mathrm{T}$ cells and regulatory T cells. Haematologica 2011, 96, 1204-1212.

96. Hanley, P.J.; Cruz, R.Y.; Melenhorst, J.; Scheinberg, J.; Blaney, J.; Savoldo, B.; Dotti, G.; Heslop, H.; Rooney, C.M.; Shpall, E.J.; et al. Naive T-cell-derived CTL recognize atypical epitopes of CMVpp65 with higher avidity than CMV-seropositive donor-derived CTL-A basis for treatment of post-transplant viral infection by adoptive transfer of T-cells from virus-naive donors. Cytotherapy 2013, 15, S9. 
97. Barker, J.N.; Doubrovina, E.; Sauter, C.; Jaroscak, J.J.; Perales, M.A.; Doubrovin, M.; Prockop, S.E.; Koehne, G.; O’Reilly, R.J. Successful treatment of EBV-associated posttransplantation lymphoma after cord blood transplantation using third-party EBV-specific cytotoxic T lymphocytes. Blood 2010, 116, 5045-5049.

98. Doubrovina, E.; Oflaz-Sozmen, B.; Prockop, S.E.; Kernan, N.A.; Abramson, S.; Teruya-Feldstein, J.; Hedvat, C.; Chou, J.F.; Heller, G.; Barker, J.N.; et al. Adoptive immunotherapy with unselected or EBV-specific $\mathrm{T}$ cells for biopsy-proven $\mathrm{EBV}+$ lymphomas after allogeneic hematopoietic cell transplantation. Blood 2012, 119, 2644-2656.

99. Uhlin, M.; Okas, M.; Gertow, J.; Uzunel, M.; Brismar, T.B.; Mattsson, J. A novel haplo-identical adoptive CTL therapy as a treatment for EBV-associated lymphoma after stem cell transplantation. Cancer Immunol. Immunother. (CII) 2010, 59, 473-437.

100. Leen, A.M.; Bollard, C.M.; Mendizabal, A.M.; Shpall, E.J.; Szaboles, P.; Antin, J.H.; Kapoor, N.; Pai, S.Y.; Rowley, S.D.; Kebriaei, P.; et al. Multicenter study of banked third-party virus-specific $\mathrm{T}$ cells to treat severe viral infections after hematopoietic stem cell transplantation. Blood 2013, 121, 5113-5123.

101. Qasim, W.; Derniame, S.; Gilmour, K.; Chiesa, R.; Weber, M.; Adams, S.; Rao, K.; Amrolia, P.; Goulden, N. Third-party virus-specific $\mathrm{T}$ cells eradicate adenoviraemia but trigger bystander graft-versus-host disease. Br. J. Haematol. 2011, 154, 150-153.

(C) 2014 by the authors; licensee MDPI, Basel, Switzerland. This article is an open access article distributed under the terms and conditions of the Creative Commons Attribution license (http://creativecommons.org/licenses/by/3.0/). 